\title{
Future perspectives of Therapeutic Claims of an Ethnopharmacological Drug Ipomoea carnea Jacq. - A Critical Review
}

Review Article

\section{Nilima Wadnerwar ${ }^{1 *}$, Meena Deogade ${ }^{2}$}

1. Associate Professor, Agadtantra, Department of Agadtantra, Mahatma Gandhi Ayurved College, Hospital \& Research Centre, Salod (H), Datta Meghe Institute of Medical Sciences (DU), Wardha, Maharashtra, India.

2. Associate Professor, Dravyaguna, All India Institute of Ayurveda, New Delhi.

\begin{abstract}
Ipomoea carnea Jacq is an ethnopharmacological drug used for various indications by healers. As the herbal medicines are becoming endangered, ethanopharmacological drug can be used efficiently as they are available abundantly. The aim of this article is to highlight the therapeutic uses of Ipomoea carnea and to stress the use of ethanopharmacological drug vividly in the treatment. Materials and Methods: The data was located from books including ethnopharmacological drugs, Indian flora, traditional medicine and articles in various journals out of which only the data related to Identification of the species, pharmacological researches, therapeutic and other uses of Ipomoea carnea Jacq was selected. The data was segregated, edited, consolidated and reviewed critically to explore the therapeutic potential of the drug. Result: Phytochemical, invivo and invitro pharmacological studies indicate the therapeutic potential of Ipomoea carnea but there is scarcity of clinical evidences to prove their efficacy and safety in human beings. Discussion and Conclusion: Ipomoea carnea has significant pharmacological and therapeutical value. Though it is used as folk medicine, no clinical study has been conducted to evaluate the efficacy or to evaluate the toxic potential of Ipomoea carnea leaves, seeds or any other part.
\end{abstract}

Key Words: Ipomoea carnea, Ethnopharmacology, Ethnomedicine, Swainsonine.

\section{Introduction}

In India, traditional medicines have been used since long ago. Ethnomedicine is the study or comparison of the traditional medicine based on bioactive compounds in plants and animals and practiced by various ethnic groups. Ethnopharmacology is a study of ethnic groups and their use of plants compounds. It is linked to medicinal plants and ethanobotany.

Ipomoea is a large and complex genus comprising over 600 species of vines and shrubs widely distributed throughout the tropics.(1) In India, over 60 species of Ipomoea are reported.(2) Ipomoea carnea Jacq commonly known as Beshrama in Maharashtra is a folklore medicine and belongs to convolvulacae family. It is also called as pink morning glory and bush morning glory. It grows in India as weed or wild plant naturally in waste lands, wet land, roadside, canals and drain banks abundantly. Its flowers are used in bathukamma which is a state festival of Telangana state. (3)

The plant is harvested from the wild for local use as a food and a medicine. It has escaped from

\section{* Corresponding Author:}

\section{Nilima Wadnerwar}

Associate Professor, Department of Agadtantra, Mahatma Gandhi Ayurved College, Hospital \& Research Centre, Salod (H), Datta Meghe Institute of Medical Sciences (DU), Wardha, Maharashtra, India. Email Id: dr.nilima wadnerwar@,rediffmail.com cultivation and become naturalized in many areas, often being classified as invasive. The plant is grown as a hedge and green manure. It is traditionally grown in living fences in the northwestern Himalayas, where it helps to exclude livestock and other animals; mark out land boundaries. It is well distributed in India and found particularly in Maharashtra, Chhattisgarh and Madhya Pradesh, Kota and Ghuntaghat in Rajasthana. (4) This plant is spread all over the world including American tropics, Argentina, Brazil and Bolivia, (5) Pakistan, Srilanka etc. (6)

Many claims have been made by traditional healers for ethnomedicine. But there is lack of evidences; hence there is need of validation and to generate the evidences regarding claims. Due to the deforestation and changing climatic conditions, a wide number of species of medicinal plants are getting endangered whereas in India, ethnomedicine is available abundantly and used as folklore medicine. The ethnomedicines can reduce the burden of pharmacopoeal herbal medicines if they are studied and proved scientifically with evidences. Hence, this article aims to highlight the therapeutic claims of ethnopharmacological drug, Ipomoea carnea Jacq. It gives thorough knowledge about the use of Ipomoea carnea as a medicine. It provokes the significance of ecofriendly drug which can fulfill the demand of herbal medicine. The article emphasizes upon the use of ethnopharmacological drug vividly in the treatment so that the burden of endangered herbal medicine can be reduced. 
Aim

The aim of this article is to identify the therapeutic potential of ethnopharmocological drug, Ipomoea carnea Jacq.

\section{Objectives}

To highlight the therapeutic utility of Ipomoea carnea Jacq from different literature sources.

\section{Material and methods}

The data was located from books including ethnopharmacological drugs, Indian flora and traditional medicine as well as from articles in various journals of botany, taxonomy, agriculture, ethnopharmacology etc. Search engines like pubmed, google search, science direct etc were used for searching the data. The data portal like AYUSH, DHARA and TKDL were also used for search process. Studies published on Ipomoea carnea within the duration from 1981 to March 2021 were searched in the form of review articles, analytical and experimental studies, clinical studies and ethnomedicinal surveys from the various peer reviewed journals which are available online on free access. The key word like "Researches on Ipomoea carnea", "Folk uses of Ipomoea carnea", "Toxicity of Ipomoea carnea", Pharmacological properties of Ipomoea carnea" "Ethnomedicinal survey on Ipomoea carnea" were used for searching. Publications available in English language were included in the study.

From the available data, only the data related to identification of the species, pharmacological and clinical researches, therapeutic and other uses of Ipomoea carnea Jacq was selected. The data was segregated into morphology of the plant, phytochemical, invivo and invitro pharmacological studies, therapeutic and other utilities of Ipomoea carnea Jacq. The data was edited to explore the therapeutic significance of Ipomoea carnea Jacq. All the pharmacological evidences and therapeutic uses of Ipomoea carnea were consolidated to stress on its therapeutic potential.

\section{Observations and results}

Total 73 articles were searched out of which 7 articles ( 5 articles and 2 ethno botanical surveys) were rejected as they were not directly related with the criteria. Out of 66 articles, review articles were 21, experimental studies were 28, 2 ethno medicinal surveys, chapters from 4 books and one experimental research protocol were included in the study. In over all search, no clinical study or randomized control trial was found regarding the therapeutic efficacy of Ipomoea carnea. The experimental studies are conducted in different parts of the world including India. Out of these articles, 11 articles were published in Pubmed journals, 9 in Scopus journals and rest of the articles in different peer reviewed indexed journals. From year 1981 to 2000, 5 review articles and 4 experimental studies were published. From year 2001 to 2021, 16 review articles, 34 experimental studies 2 ethno medicinal surveys, chapters from 4 books and one experimental research protocol were published. But since last four decades, no clinical study was published to provide the evidences for therapeutic claims of Ipomoea carnea.

\section{Contribution of the review articles}

Most of the review articles have contributed in emphasizing the geographical distribution, morphological features, cultivation method, phyto constituents and their pharmacological activities along with traditional, folk uses as well as other ecological utilities of Ipomoea carnea plant.

\section{Contribution of the experimental studies}

Various preclinical experimental studies have established different pharmacological properties of Ipomoea carnea plant providing validated evidences for the clinical or medicinal use of the plant along with toxicity profile the drug which is a very important step in drug development.

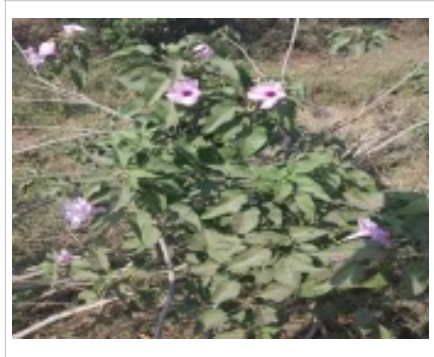

Fig 1: Ipomoea carnea Jacq plant from field

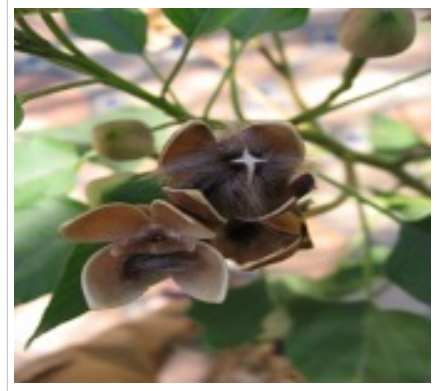

Fig 3: Ipomoea carnea Jacq dehiscent fruit

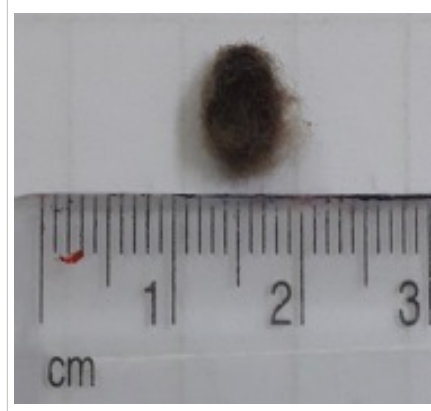

Fig 5: Ipomoea carnea Jacq seed with trichomes

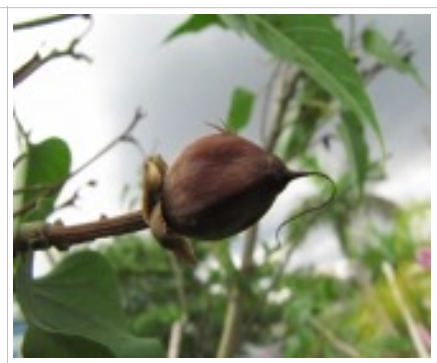

Fig 2: Ipomoea carnea Jacq fruit

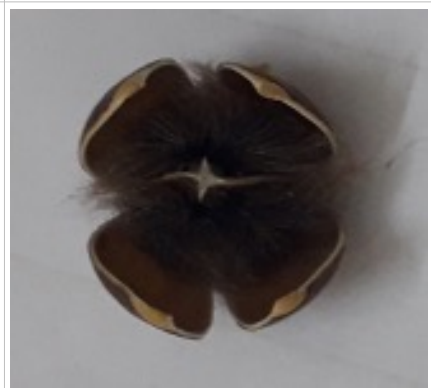

Fig 4: Ipomoea carnea Jacq dehiscent fruit

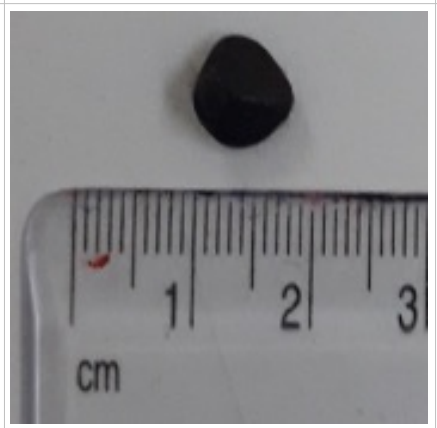

Fig 6: Ipomoea carnea Jacq seed without trichomes

\section{Phytochemical significance}

Ipomoea carnea is a rich source of chemical compounds, pigments, steroid etc. Chloroform extract of Ipomoea carnea showed the presence of steroids, carbohydrates alkaloids, phenolic compounds, saponins, 
xanthoproteins and flavonoids.(7) It was studied that when Ipomoea carnea flowers were analyzed with Petroleum ether and Hydro alcoholic treatment then Flavonoids, Tannins, Glycosides, Alkaloids, Carbohydrates, and Phenolic compound were observed. Along with glycosides and alkaloids, it also contains reducing sugars, flavonoids, fatty acid, esters, alcohol and tannins. (8)

Swainsonine is found in all parts of Ipomoea carnea. It is lysosomotropic compound which produces neurological disorders. The nortropane alkaloids calystegines B2 and C1, together with swainsonine have been detected in the leaves collected in Mozambique where goats were intoxicated. (9)

The roots are reported to contain 2-Ethyl-1,3dimethylbenzene, 2-(12-Pentadecynyloxy) tetrahydro2H-pyran, 3-Furanyl[2-hydroxy-4-methyl-2- -(2methylpropyl) cyclopentyl]- methanone, 2,2Dideuterooctadecanal, Hexadecanoic acid, Linoleic acid. The stem of the plant contains 2-(12Pentadecynyloxy) tetrahydro- 2H-pyran, 1-Octadecanol, Hexadecanoic acid, Epiglobulol, Squalene, 1Octadecanol.(10)

The leaves of the plant showed the presence of thirteen compounds which include hexa decanoic acid, stearic acid, 1, 2 diethyl phthalate, n-octadecanol, octacosane, hexatriacontane, tetracontane, 3diethylamino-1- propanol.(11) Also the presence of swainsonine and calystegines B1, B2, B3, and C1 were detected in the aqueous ethanolic extract of leaf.(9) Quercetin was present in Ipomoea carnea leaves. (12) Polysaccharide Ipomose and saponins and significant amount of phenols, terpenoid and steroid. (13)

The flowers of the plant are reported to contain flavonoids, tannins, glycosides, alkaloids, carbohydrates and phenolic compound.(7) Flowers contain maximum amount of phenolic compounds while stem contain their minimum amount. Phenolic values lies between 45 to $73 \mathrm{mg}$ catechol equivalent/gm.(14) The presence of swainsonine and calystegines $\mathrm{B} 1, \mathrm{~B} 2, \mathrm{~B} 3$, and $\mathrm{C} 1$ was confirmed in the aqueous ethanolic extract of flowers. (9) Polysaccharide Ipomose and saponins and significant amount of phenols, terpenoid and steroid were also present.(13)

Swainsonine and calystegines B1, B2, B3, and $\mathrm{C} 1$ were found in seeds of the plant Ipomoea carnea.(9)
Its seed oil was found to contain linoleic acid (VII) and oleic acid (VIII).(15)

\section{Folk and pharmacological practices}

Ipomoea carnea is used as folk medicine.(16) It has a very high medicinal value.(17) Leaves, flower, seed and root are the useful parts of Ipomoea carnea. Leaves are used as purgative. Paste of leaves is applied on a sore known as 'Haja' which occurs in between toes and fingers due to fungal infection. Leaves are cooked and eaten as a vegetable even though they are slightly purgative. Roots have laxative effects and are boiled and used to provoke menstruation, and are traditionally a treatment for skin diseases.

Latex or Milky sap of plant has been traditionally used to treat Leucoderma (13) in Chhattisgarh, India and other related skin diseases. The latex of plant applied locally to relief boils and pimples in the body skin, used locally to alleviate the stomachache, nodules in breast, muscular pain and swelling. Latex is also used as an antiseptic in skin diseases. Stem juice is used as an antiseptic in cuts and injuries.(18) Leafy latex of Ipomoea carnea are already reported the presence of flavonoid and evaluated for wound healing activity.(19) The Cyclophosphamide (20) present in Ipomoea carnea is used as aphrodisiac, purgative and cathartic.

It contains a component identical to marsilin which is used as a sedative and anticonvulsant.(21) It also contains a glycosidic saponin which has anticarcinogenic and oxytoxic properties.(22) Ash of Ipomoea carnea leaves was used in a skin disease in some rural areas of Chhattishgarh, India.(16) Extract of the whole plant prepared in hot water was widely used as anti-rheumatic remedy in Bolivia.(23) The plant is also believed to reduce the teratogenic effect of cyclophosphamide.(20) In many folk medicines, it is used as aphrodisiac, purgative as well as cathartic.(24) Plant sap,(25) leaves and flowers are used in scorpion sting. (26) Leaves are used to reduce high blood pressure, on swelling, on boils and in snake bite. The plant is used against dermatoses without referring to any sources.(27) From the field survey in Wardha district of Maharashtra state in India, it came to know that its leaves are used for scorpion bite. The fresh leaves are crushed and its juice is poured on bite site. The paste of leaves is applied and kept over bite site till the pain subsides.

\section{Table 1: Summarizing pharmacological and therapeutic properties of different parts of Ipomoea carnea Jacq.}

\section{Parts of Ipomoea carnea Jacq}

Leaves

Flowers

Buds

Root

Latex

Seed

Whole plan

\section{Pharmacological activity}

Purgative, Aphrodisiac, Cathartic, Anti-diabetic, Antimicrobial, Antifungal, Anticancer, Cardiovascular Activity, Anti-inflammatory, Hepatoprotective, Anxiolytic, Wound healing, Phytotoxic, Embryo toxic, Neurotoxic

Laxative

Antiseptic, Wound healing activity

Analgesic and antiseptic

\section{Therapeutic uses}

Fungal infection, skin disease, Purgative, scorpion sting, high blood pressure, swelling, Sore, boils, snake bite, Sprain (28)

Scorpion sting

Scorpion sting (29)

Purgative, Menstruation, skin diseases. Leucoderma, boils and pimples stomach ache, nodules in breast, muscular pain and swelling, cuts and injuries, scorpion sting

Rheumatic disease, Dermatoses 
Pharmacological Activity

Anti-bacterial $(30,31)$

Anti-fungal

$(32,33)$

Anti-oxidant $(13,34)$

Antimicrobial activity (35)

Anti-cancer (36)

Anti-convulsant (37)

Sedative (37)

Anti-inflammatory

(38)

Anxiolytic activity

$(37,39)$

Immunomodulator y Activity $(40,41)$

Peroxide production activity (40)

Anti-diabetic activity $(12,42)$

Anti- Malarial

activity (43)

Hepatoprotective

activity (44)

Cardiovascular

Inhibition (45)

Wound healing

Activity (46)

Wormicidal

activity (3)

Insecticidal

Property (47)

Embryotoxic effect (48)

Table 2: Summarizing outcome of pharmacological activities of Ipomoea carnea Jacq.

Anti-bacterial activity of silver nanoparticles was found against selected human pathogens viz. Bacillus cereus, Bacillus subtilis, Proteus vulgaris, Stapyhlococcus aureus, Pseudomonas aeruginosa, Aeromonas hydrophila, Klebsiella pneumonia and Salmonella typhi.

Chloroform and Methanol extract of Ipomoea carnea show antifungal activity against Alternaria alternate and curvularia lunata as well as against eleven pathogenic and nonpathogenic fungi.

Dose dependant free radical scavenging property in all the models was observed in in vitro antioxidant activity using different models of screening viz. DPPH radical scavenging, ABTS radical scavenging, iron chelating activity, nitric oxide scavenging assay, and alkaline DMSO assay.

Crude acetone extracts of Ipomoea carnea leaves showed Antimicrobial activity against Proteus vulgaris and Salmonella typhimurium. Crude ethanol extract of Ipomoea carnea leaves showed Antimicrobial activity against pseudomonas aeruginosa.

Hydroalcoholic extract of Ipomoea carnea leaves possess significant anticancer property with the dose dependent effect.

Polar extract of Ipomoea carnea reduces the MES-induced convulsion n extension phase and stupor phase at a dose ranging from $200 \mathrm{mg} / \mathrm{kg}$ to $400 \mathrm{mg} / \mathrm{kg}$.

Aqueous and alcoholic extracts showed the CNS depressant activity in dose dependent manner.

Aqueous extracts of mature green leaves found to possess a strong anti-inflammatory activity at dose of $500 \mathrm{mg} / \mathrm{kg}$ in comparison to Etorikoxib $6 \mathrm{mg} / \mathrm{kg}$.

Ipomoea carnea methanolic extract showed greater anxiolytic effect as compared to Ipomoea carnea leaf aqueous extract (doses of $32.5 \mathrm{mg} / \mathrm{kg}$ and $16.2 \mathrm{mg} / \mathrm{kg}$ ) and diazepam.

Consumption of Ipomoea carnea in a dose of $7 \mathrm{gm} / \mathrm{kg}$, causes less food intake, reduction in body weight, increase in spleen/body weight ratio, decrease in the thymus/body weight ratio, and histological changes.

Swainsonine has immune effect due to glycoprotein metabolism. Due to this rheumatoid arthritis (RA) was developed to both adult ( 70 days old) and juvenile rats (21 days old).

Administration of low dosage of Ipomoea carnea increases body process activity and peroxide production by macrophages.

Aqueous extract of Ipomoea carnea leaves reduces the blood glucose level in streptozotocin induced diabetic rats and increased the glucose tolerance in normal rats.

Synergistic effect of insecticides with plant extracts of Ipomoea carnea is reported against malarial vector, Anopheles stephens.

Hepatoprotective activity of Ipomoea carnea was found in $\mathrm{CCl} 4$ induced hepatotoxicity in rat.

Ipomoea carnea may produce a positive inotropic effect on isolated frog heart by sodium extrusion or release of the intracellular calcium.

Ethanolic extract of Ipomoea carnea effectively stimulates wound contraction and significantly increased tensile strength of skin wound tissues. (54)

Ethanol:water extract of Ipomoea carnea showed potent anthelmintic activity against Indian earthworm spheritima posthuma and was equipotent to standard anthelmintic drug.

Benzene and chloroform extracts of Ipomoea carnea showed presence of Cholestan-3-one which is a steroidal compound and it has a high insecticidal property.

Prenatal ingestion of the Ipomoea carnea aqueous extract in rats induces embryotoxicity. These effects are associated to an active principle from Ipomoea carnea acting on maternal homeostasis, or directly in the conception.

\section{Effect on Nervous System}

When goats were fed with fresh leaves, flowers and stems of Ipomoea carnea for 45 to 60 days then Hirsute coat, depression, difficulty to stand up, ataxia, hypermetria, wide-based stance, incoordination of muscular movements, intense tremors, spastic paresis, abnormal postural reactions, nystagmus, hyperreflexia, hypersensitivity to sound, head tilting and loss of equilibrium were observed in all treated animals. The cerebellum which processes information from other nervous areas, mainly spinal cord and sensory receptors, with the purpose to coordinate skeletal muscle movements was affected due to Ipomoea carnea intoxication. (49) The functional units of the cerebellum cortex are the Purkinje cells; these cells send inhibitory projections to the deep cerebellar nuclei. These neurons were severely affected in this intoxication, including necrosis in some of them. (50) Leaves can lead to antidepressant activity of CNS. (51)

\section{Toxicity profile}

Seeds and leaves are toxic and it can be hazardous to cattle, the toxicity is related to the bioaccumulation of selenium species in leaves but mostly in seeds. (52) Leaves are toxic to livestock. It is reported to have phytotoxic and stimulatory allelopathic effects. Leaves have toxic effects on nervous system and maternal reproductive system. It is embryo toxic and causes skeletal and visceral abnormalities and malformations. Feeding of fresh green leaves to goat caused signs of toxicity viz. dullness, ataxia, paralysis, lacrimation, diarrhea and nasal discharge. Two goats died on $22^{\text {nd }}$ and $55^{\text {th }}$ day with chronic neurotoxic symptoms such as ataxia, weakness of lumber region, paralysis of hind and fore limbs with progressive 
emaciation.(53) Consumption of the seeds may cause negative side effects, including vomiting, nausea and indisposition; probably as a result of non-water-soluble alkaloids. Visions of "small people" are very common, as well as LSD-like sensations, although the effects are not exactly like LSD. The seeds also seem to stimulate the uterus, probably due to the alkaloid ergonovine. (54)

When ethanolic extract of Ipomoea carnea leaves was tested for its toxicity against fish Guppy (Poecilia reticulata) with $0.025,0.050,0.07$ and $0.1 \mathrm{mg} /$ $\mathrm{ml}$ concentrations, it showed toxic effect and caused mortality in guppy fishes. It showed change in behaviour like surfacing, gulping, mucous secretion from skin, omitting, increase in rate of gill opercular movement, loss of body balance and change in body colour to white. (55)

The Swainsonine is the main toxic principle present in Ipomoea carnea. It is an indolizidine alkaloid with significant physiological activity. It is an alpha mannosidase and mannosidase II inhibitor that alters glycoprotein processing and causes lysosomal storage disease. It is water soluble and hence it distributes rapidly in many parts of the body. It is excreted rapidly through urine. Some portion is also excreted in milk in lactating animals. It is present in number of plant species worldwide and causes severe toxicosis in livestock grazing these plants. Swainsonine from locoweed causes acute intoxication in horses, goats, and sheep, in addition to chronic poisoning in rabbits, rats, and mice. Consumption of these plants leads to a chronic wasting disease characterized by weight loss, depression, altered behavior, decreased libido, infertility and death. (48)

The fast excretion rate indicates that occasional consumption of the locoweed for short duration will not produce serious toxic effects but continuous consumption even at low dose causes severe toxicity. The Swainsonine, Calystegines B1, B2, B3 and C1 are present in leaves, flowers and seeds. (7) The toxicity is due to bioaccumulation of selenium species more in seeds in comparison with leaves. Hence, seeds are more toxic. Swainsonine has immune effect due to glycoprotein metabolism. Due to this rheumatoid arthritis (RA) was developed to both adult and juvenile rats. Hence, Swainsonine modulates the immune function.(41) Severe reproductive and developmental toxicities are associated with swainsonine poisoning. (56)

However, the plant extracts has not produced death up to dose level $2000 \mathrm{mg} / \mathrm{kg}$ and did not cause any toxic effect up to dose of $3000 \mathrm{mg} / \mathrm{kg}$ in mice in acute toxicity study. (37)

\section{Ecological significance of Ipomoea carnea}

Ipomoea carnea is extremely hardy and is resilient to several forms of chemical and biological control. The stem is used as a raw material for paper making. (57) Stem is also used as fire wood. It is a good raw material which is replacement of wood. Soda lignin and Soda Anthraquinone lignin obtained from wood and Ipomoea carnea is almost same. The leaves are used as fertilizer. The plants are also used for fencing. Colourful flowers are often grown as ornamentals, and a number of cultivars have been developed.

It has been observed that Ipomoea carnea is a suitable raw material for the production of activated carbon. It is effective in the removal of copper from aqueous solution. It was concluded that the activated carbon produced from Ipomoea carnea by zinc chloride activation has better adsorbing capacity of copper than the raw adsorbent. (58) Ipomoea carnea is used as a potential source of textile and energy. It has pest management activity. The plant is grown as a hedge and green manure.

The farmers of Chhattisgarh used Ipomoea carnea with other herbs and cow urine to repel away the insects and pathogens in crop field. (2) This type of uses of the plant shows the presence of bioactive molecules which are responsible for entomological activities. There are reports on synergistic effect of insecticides with plant extracts of Ipomoea carnea against malarial vector, Anopheles stephensi. (43) Aqueous and petroleum ether extracts of Ipomoea carnea leaves have the potential to be used as an ideal eco-friendly approach for the control of the major lymphatic filariasis vector, Culex quinquefasciatus (59) Aqueous extract of leaves showed nematocial activity and acetone extract of leaves showed insecticidal effect. (60) The changes in leaf surface traits can be used as air pollution marker. (61) Leaf surface can also be used as dust scavengers. The leaves are palatable for various fish species. Entire Ipomoea carnea subspecies fistulosa is used as a raw material for paper-bag production in the surroundings of Tiruchirapalli and along the Eastern Ghats in India. Dried stem material is also used as firewood in Rajasthan, because of its yellow flame. (62)

\section{Discussion}

The curiosity has given birth to some researches on Ipomoea carnea. Phytochemical researches are conducted to find out various phytoconstituents which are responsible for pharmacological actions of Ipomoea carnea. The pharmacological activities are also proved successfully in invitro and in vivo experiments. All the studies mainly include leaves of Ipomoea carnea. $(11-14,35-39,42,45-47)$ No clinical studies are conducted to evaluate the efficacy of Ipomoea carnea leaves, seeds and other useful parts. It may due to its toxic potential, Swainsonine which is maximum in seeds $(0.0332 \%)$ in comparison with leaves $(0.0029 \%)$ and flower $(0.0028 \%)$. (63) Molyneux et al. detected swainsonine in the seeds and estimated the level as $0.058 \%$ by gas chromatography-mass spectrometry (GC-MS). (64) But a conservative approach suggests that levels of Swainsonine in excess of $0.001 \%$ should be of concern. (65) Phytoconstituents of this plant viz-aviz tannin have antibacterial, antifungal and antiviral activities. However, Cholestan-3-one is a steroidal compound and it has a high insecticidal property. That may be the reason it shows antimicrobial activity against various microorganisms. So it is a good option for infectious or communicable diseases. (47) 
Polyphenols and alkaloids present in Ipomoea carnea can be used as reducing agents in the synthesis of nanoparticles. It was suggested that these nanoparticles can be used in the fabrication of hospital clothes, gloves and masks to avoid the spread of infection among healthcare workers. (30) This will have a wider scope to prevent various infections in hospital as it is needed in current situation. The leaves of Ipomoea carnea are effectively used in muscle sprains. (66) Hence, it may be better muscle relaxant for external applications. Ethnomedicines have this kind of wide use in therapeutics. $(67,68,69)$

Since Vedic period, plants are used for medicinal purposes. Later on Charaka and Sushruta has used different herbal plant parts for different ailments of the human being. Then, it is reported that traditional healers use near about 2500 plant species and 100 species of plants which serve as regular sources of medicine. Traditional herbalists, Hakims and Vaidyas were collecting plant materials from the forest on the basis of the knowledge of plants they have received traditionally from their mentors and experiences. (70)

Ipomoea carnea Jacq is also one of the ethnic plants used by traditional healers for various pathological conditions. As it is available abundantly and used for treatment can be thought about to use as an alternative of endangered or rare species. Though the drug is toxic and has high therapeutic value, there should be some measure to reduce the toxicity or to combat its toxic effects with the help of some procedure or antidote. In the proposed research, the author may be able to find out any measure to reduce the toxicity of the Ipomoea carnea seeds. (71) Evidence based medicine demands scientific data related to efficacy and safety to save the mankind. Dose and duration of administration of the drug plays an important role in the treatment. To study the safety and efficacy of Ipomoea carnea, dose and duration of administration is a challenge. If these challenges are overcome, the ethnopharmacological drugs can be used vividly in the treatment so that the burden of endangered herbal medicine can be reduced.

\section{Conclusion}

From the review of literature and researches conducted on Ipomoea carnea, it can be concluded that it has significant pharmacological value and it is therapeutically important. Though Ipomoea carnea is used as folk medicine in traditional medicinal systems, no clinical study has been conducted to evaluate the efficacy or to evaluate the toxic potential of Ipomoea carnea leaves, seeds or any other part. The drug is toxic but no antidote is available for its toxicity. Hence, further scientific research is recommended to evaluate the efficacy and toxic potential of Ipomoea carnea leaves as well as seeds so that it can be used as a substitute of pharmacopoeal drugs for various indications.

\section{Conflict of Interest: NIL}

Acknowledgements: I acknowledge Shri Shyamraoji Timande, Gardner, Mahatma Gandhi Ayurved College, Hospital \& Research Centre, Salod (Hirapur) and resident of Salod (Hirapur), Wardha, Maharashtra, India for his help to locate the plants and to provide information during field survey.

I acknowledge Datta Meghe Institute of Medical Sciences (Deemed to be University), Wardha, Maharashtra, India for their financial support.

\section{References}

1. Miller R, Rausher MD, Phylogenetic systematic of Ipomoea (Convolvulaceae) based on ITS and waxy sequences, Systematic Botany, 1999; 24 (2): 209-227.

2. Odhia P. Major Ipomoea Species (Morning glories) of Chhattisgarh India: Natural Occurance. Traditional Medicinal knowledge \& Trade; 2001-2003.

3. Sravan Kumar P, Santhosh A, Manasa K et al, In-vitro antihelminthic activity, phytochemical screening and TLC studies of ethanol-water extraction on Ipomea carnea flower using in - state festival of Telangana (bathukamma), Journal of Pharmaceutical Research, 2018; 7(4):50-55.

4. Ekka RN, Dixit, VK, Ethnopharmacognostical studies of medicinal plants of Jashpur district Chattisgarh, International Journal of Green Pharmacy, 2007; 1(1): $2-4$.

5. Shinners LH. Manual of the Vascular Plants of Texas. Correll DS and Johnston MC, editors. Texas. Renner, 1970. 1241-1261.

6. Dassanayake MD, Fosberg FR. A Revised Handbook to The Flora of Ceylon. Vol 1. New Delhi: Amerind Publishing Co. Pvt. Ltd; 1980. 508.

7. Gupta A, Nayak S, Mallik A, Preliminary Phytochemical Screening of hydroalcoholic Flower Extract of Ipomoea fistulosa, International Journal of Current Trends in Science and Technology, 2010; 1(2):37-40.

8. Nandkumar P, Pulp Blending and its Effects on the Strength Properties of Ipomoea Carnea Jacq, Journal of Environmental Research and Development, 2009; 3(4):1088-1093.

9. Balogh KK, Dimande AP, Van der Lugt JJ, et al. Lysosomal storage disease induced by Ipomoea carnea in goats in Mozambique, Journal of Veterinary Diagnostic Investigation, 1999; 11: 266-273.

10. Sahayaraj K, Kombiah P, Dikshit AK, et al. Chemical constituents of the essential oils of Tephrosia purpurea and Ipomoea carnea and their repellent activity against Odoiporus longicollis, Journal of Serbian Chemical Society, 2015; 80(4):465-473.

11. Adsul VB, Khatiwora E, Manik K et al, GC-MS Study of fatty acid, esters, alcohol from the leaves of Ipomoea carnea, International Journal of Pharmatech Research, 2009; 1(4): 1224 - 1226.

12. Khan YT, Raina R, Verma KP et al, Phytochemical constituents and antidiabetic potential of Ipomoea carnea Jacq leaves extracts, Journal of Experimental and Integrative Medicine, 2014; 4: 137-142.

13. Adsul VB, Khatiwora E, Deshpande NR, Evaluation of Antioxidant activity of Ipomoea carnea leaves, 
Journal of Natural Products and Plant Resources, 2012; 2 (5): 584-588.

14. Khatiwora E, Adsul VB, Manik M et al, Spectroscopic determination of total phenol and flavonoid contents of Ipomoea carnea, International Journal of Chemical and Technical Research, 2010;2(3): 1698-1700.

15. Agarwal KA, Bansal KA, Upadhyay JS, Chemical Engineering World, 1993;28(2), 51-55.

16. Agarwal RK, Upadhyaya RK, Preliminary pharmacological studies on the glycoside obtained from the Ipomoea carnea Jacq, Indian Drugs Pharma, 1978;13(3): 7-8.

17. Shivrajan VV. Ayurvedic Drugs and Their Plant Sources. 1996. 256-273.

18. Dash SS, Mishra MK, Tribal uses of plants from Narayanapatna region of Koraput district, Orissa, Ancient Science of Life, 1996;15 (3):230-237.

19. Ambiga S, Narayanan R, Gowri D et al. Evaluation of wound healing activity of Ipomoea carnea Jacq, Ancient Science of Life, 2007;26(3 \& 4): 45 - 51.

20. Phillips O, Gentry AH, Reynal L et al. Quantitative Ethnobotany \& Amazonian Conservation, Biological Conservation, 1994; 8: 225-248.

21. Meira M, Silva EP, David JM et al. Review of the genus Ipomoea: traditional uses, chemistry and biological activities, Brazilian Journal of Pharmacognosy, 2012;22: 682-713.

22. Sharma A, Bachheti RK, A review on Ipomoea carnea, International Journal of Pharmacy and Biological Sciences, 2013;4(4): 363- 377.

23. Shaltout KH, Al-Sodany YM, Eid EM, The biology of egyptian woody perennials 2 . Ipomoea carnea Jacq, Assuit University Bulletin for Environmental Researches, 2006; 9 (1).

24. Ved GA, Kinhal K, Ravikumar MK et al. Threat Assessment and Management Prioritization for Medicinal Plants of Chattisgarh and Madhya Pradesh, FRLHT, Bangalore, India. 2004. 418.

25. Khanna KK, Mudgal V, Shukla G et al. Unreported ethnomedicinal uses of plants from Mirzapur district, Uttar Pradesh, Journal of Economic and Taxonomic Botany, Additional series, 1996, 112-117.

26. Srivastava D, Shukla K, Pharmaceutical efficacy of Ipomoea carnea. Biological Forum - An International Journal, 2015; 7(1): 225-235.

27. Van den Berg ME, Contribution to the knowledge of medicinal flora of Mato Grosso, Science and Culture, 1982; 34: 163-170.

28. Chattopadhyay A.Medicinal use of Litosa, Bhat kaiya and Behaya in Varanasi. Nagarjuna, 1982; 25: 110.

29. Maheshwari JK, Singh JP. Plants used in ethnomedicine by the Kols of Alahabad district, Uttar Pradesh. Bull.medico -ethnobot. Res.1984; 5:105-121.

30. Daniel SC, Banu BN, Harshiny $\mathrm{M}$ et al. Ipomea carnea - based silver nanoparticle synthesis for antibacterial activity against selected human pathogens, Journal of Experimental Nanoscience, 2014; 9(2): 197-209.

31. Khatiwora E, Adsul VB, Kulkarni $M$ et al. Antibacterial activity of Dibutyl Phthalate: A secondary metabolite isolated from Ipomoea carnea stem, Journal of Pharmacy Research, 2012; 5(1): 150-152.

32. Nidiry ES, Ganeshan G, Lokesha AN, Antifungal activity and isomerization of octadecyl p-coumarates from Ipomoea carnea subsp. Fistulosa, Natural Products Communication, 2011; 6(12):1889-92.

33. Guleria S, Kumar A, Antifungal activity of some Himalayan medicinal plants using direct bioautography, Journal of Cellular and Molecular Biolology, 2006; 5: 95-98.

34. Ambiga S, Jeyaraj M, Evaluation of in vitro Antioxidant Activity of Ipomoea carnea Jacq, International Journal of Current Microbiololgy and Applied Sciences, 2015; 4(5): 327-338.

35. Agarwal RK, Uppadhay RK, Antimicrobial activity of metal complexes prepared from the leaf proteins of Ipomoea carnea Jacq, Indian Drugs and Pharmaceutical Industries, 1997; 14(2): 23-25.

36. Anand G, Sumithira G, Chinna RR et al. In vitro and in vivo anticancer activity of hydroalcoholic extract of Ipomoea carnea leaf against Ehrlich Ascites Carcinoma cell lines, International Journal of Advanced Pharmaceutical Genuine Research, 2013; 1(1): 39-54.

37. Rout SK, Kar DM, Sedative, anxiolytic and anticonvulsant effects of different extracts from the leaves of Ipomoea carnea in experimental animals, International Journal of Drug Development Research, 2013; 5(2): 232-243.

38. Khalid MS, Singh RK, Reddy IVN et al. Anti Inflammatory Activity of Aqueous Extract of Ipomoea carnea Jacq, Pharmacologyonline, 2011; 1: 326-331.

39. Bidkar JS, Bhujbal MD, Ghanwat DD et al. Anxiolytic Activity of Aqueous and Methanolic Extracts of Ipomoea carnea Leaves, International Journal of Universal Pharmacy and Bio Sciences, 2012; 1(2): $1-11$.

40. Hueza IM, Fonseca, Evaluation of immunomodulatory activity of Ipomoea carnea on peritoneal cells of rats, Journal of Ethopharmacology, 2003; 87 (2), 181-186.

41. Lunardi C, Bason C, Navone R, et al. Systemic sclerosis immunoglobulin $\mathrm{G}$ autoantibodies bind the human cytomegalovirus late protein UL94 and induce apoptosis in human endothelial cells, Nature Medicine, 2000; 6: 1183-1186.

42. Kadiyawala ALA, Prasad AK, Kumar $S$ et al. Comparative Antidiabetic Studies of Leaves of Ipomoea carnea and Grewia asiatica on Streptozotocin Induced Diabetic Rats, International Journal of Pharmaceutical \& Biological Archives, 2012:3(4): 853-857.

43. Kuppusamy A, Manoharan T, Synergistic effect of insecticides with plant extracts against malarial vector, Anopheles stephensi, Trends Life Sciences, 1992; 7(1), 39-42.

44. Bishayee A, Sarkar A, Chatterjee M, The hepatoprotective activity of carrot (Daucuscarota L) against carbon tetrachloride intoxication in mouse liver, Journal of Ethnopharmacology, 1995; 47: 69-74.

45. Bachhav KV, Burande MD, Rangari VD et al. Effect of aqueous extract of Ipomoea carnea leaf on isolated 
frog and mouse heart, Indian Journal of Experimental Biology, 1999; 37(11): 1080-1084.

46. Shukla R, Gupta G, Kashaw SK et al. Wound healing effect of ethanolic extract from Morning Glory (Ipomoea carnea Jacq.) leaves by using different models in rats, Pakistan Journal of Pharmaceutical Sciences, 2018;31(4):1355-1361.

47. Sahayaraj K, Ravi C, Preliminary phytochemistry of Ipomea carnea Jacq and Vitex negundo Linn. Leaves, International Journal of Chemical Science, 2008; 6(1): $1-6$.

48. Hosomi RZ, Souza H de, Górniak SL, Embryotoxic effects of prenatal treatment with Ipomoea carnea aqueous fraction in rats, Brazilian Journal of veterinary Research and animal Science, 2008; 45(1): $67-75$.

49. Rios E, Cholich L, Silva J et al. Histopathological lesions in central nervous system of goats poisoned by Ipomoea carnea Intoxicacion en cabras, Review of veterinary medicine, 2008; 19(2): 130-134.

50. Barbosa RC, Riet Correa F, Medeiros RM et al. Intoxication by Ipomoea Sericophylla and Ipomoea Riedelii in goats in the state of Paraiba, Northeastern Brazil, Toxicon Jounal, 2006; 47: 371-379.

51. Bhattacharya SK, Ray A, Dasgupta B. Central Nervous System depressant activity of Ipomoea carnea Jacq.Indian J Pharmac 1975;7:31-34

52. Nusrat F, Mohammad MR, Khan MA et al. A review on Ipomoea carnea:-pharmacology toxicology and phytochemistry, Journal of Complementary and Integrative Medicine, 2014; 11(2): 55-62.

53. Anonymous, Reviews on Indian Medicinal Plants. Sahrma Madhu, editor. New Delhi: Medicinal plant Unit, Indian Council of Medical Research; 2013.

54. Gaur LB, Singh SP, Gaur SC et al. Facts with therapeutic significance of Ipomoea carnea, Punarnav, 2014; 2(1): 141-146.

55. Wanule DD, Balkhande JV, Effect of Ethanolic Extract of Ipomoea carnea Leaves on Guppy, Poecilia Reticulata (Peters), Bioscience Discovery, 2012; 3(2): $240-242$.

56. Chenchen $\mathrm{Wu}$, Feng $\mathrm{Ke}$, Dezhang $\mathrm{Lu}$ et al. Reproductive Toxicities Caused by Swainsonine from Locoweed in Mice, BioMed Research International, Doi:10.1155/2016/6824374.

57. Chand, Navin, Rohatgi PK, Impact toughness of Ipomoea carnea particulate-polyester composite, Journal of Materials Science Letters Netherlands: Springer Netherlands, 2005; 6 (6): 695-697.

58. Miranda MA, Dhandapani P, Kalavathy MH et al. Activated Ipomoea carnea a biosorbent for the copper sorption from aqueous solution, 2012. (www.ntu.edu.sg/pbast/_abstract) 104.Lima.Miranda.pdf.)

59. Rahuman A, Bagavan A, Kamaraj C et al. Efficacy of larvicidal botanical extracts against Culex quinquefasciatus Say (Diptera: Culicidae), Parasitology Research, 2009; 2 (7) 1337.
60. Chockalingam S, Thenmozhi S, Sundari MSN, Larvicidal activity of different products against mosquito larvae, Journal of Environmental Biolology, 1990;11: 101-104.

61. Yunus M, Kulshreshtha K, Dwivedi AK et al. Leaf surface traits of Ipomoea fistulosa Mart. ex Choisy as indicators of air pollution, New Botanist, 1982. 9: 39-45.

62. Frey R, Ipomoea carnea sp. fistulosa (Martius ex Choisy) Austin: Taxonomy, Biology and Ecology Reviewed and Inquired, Journal of Tropical Ecology, 1995; 36(1): 21-48.

63. Mitsue H, Silvana LG, Kyoko I et al. Alkaloidal Components in the Poisonous Plant, Ipomoea carnea (Convolvulaceae), Journal of Agriculture and Food Chemistry, 2003, 51: 4995-5000.

64. Molyneux RJ, McKenzie RA, O’Sullivan BM et al. Identification of the glycosidase inhibitors swainsonine and calystegine B2 in Weir vine (Ipomoea sp. Q6 [aff. calobra]) and correlation with toxicity, Journal of Natural Products, 1995, 58: 878-886.

65. Molyneux RJ, James LF, Ralphs MH et al. Polyhydroxy alkaloids glycosidase inhibitors from poisonous plants of global distribution: analysis and identification, In Plant-Associated ToxinsAgricultural, Phytochemical and Ecological Aspects; Colegate, S. M., Dorling, P. R., Eds.; CAB International: Wallingford, U.K., 1994; 107-112.

66. Kumar A, Manral U, Sharma S, Traditional remedy for Muscle Strain Using Ipomoea carnea Jacq. and Ricinus communis L. leaves in Haryana, India, International Journal of Medicinal Plants, 2014; 108, 625-631.

67. Rathi B, Rathi R. Ethno Medicinal documentation of plants used in the treatment of skin diseases by the tribal's of Karanja Ghadge Tahsil of Wardha District. Jr of School of Adv studies, 2019;2(1):22-26

68. Rathi B, Rathi R. Quantitative analysis of Medicinal plants used by the traditional healers of Karanja block of Wardha district for treating musculoskeletal disorders. International Journal of Ayurvedic Medicine, 2020;11(2):175-183.

69. Rathi B, Khobragade P, Rathi R, Gupta R. Ethnobotanical Survey on Medicinal plants used by Tribes of Karanja (Ghadge) Tahsil of Wardha District, Maharashtra, India. International Journal of Ayurvedic Medicine.2021;12(1):43-52.

70. Deogade MS, Shambharkar N, Kallianpur S et al. A Field Survey for the Diverse Flora and Fauna of Chincholi Beat of Vidarbha. Joinsysmed, 2016, 4(1): 20-27.

71. Wadnerwar NN, Deogade MS. Comparative study of Ashodhita and Shodhita seeds of Ipomoea carnea Jacq with respect to level of toxic compound (Swainsonine). International Journal of Botany Studies. 2020; 5 (6): 23-25. 